Norge begrenset. Grovt regnet halvparten i denne kategorien. Disse vil norske lesere ha beskjedent utbytte av. På den annen side er det mange kapitler som omtaler globale fenomener med høy relevans også i Norge. I så måte er noe av det aller mest leseverdige (og tankevekkende) det om kommunikasjonsproblemer med tilhørende legemiddelfeil når en pasient overflyttes fra et behandlingsnivå til et annet. Hva som styrer våre behandlingsstrategier og legemidler brukt i primær- og sekundærpreventiv hensikt, er også interessant stoff.

Utformingen er enkel, uten farger og det er kun noen få skjematiske figurer. Det er nyttig at det $\mathrm{i}$ hvert kapittel er faktaruter som oppsummerer de viktigste poengene, men det kunne med fordel vært gjort enda mer ut av selve presentasjonen av stoffet. Innholdet er svært etterrettelig - jeg fant bare én liten faktafeil under min gjennomlesing (om interaksjonen mellom paracetamol og warfarin)

En tilsvarende bok tilpasset norske forhold ville jeg ikke nølt med å anbefale til alle, både studenter og ferdige leger! Spørsmålet blir om den foreliggende boken kan ses på som tilstrekkelig interessant ut fra at det bare er halve innholdet som er relevant fra et norsk perspektiv.

\section{Olav Spigset}

Avdeling for klinisk farmakologi

St. Olavs hospital

\section{Kritisk tenking}

Levi R.

\section{Vettigare vård}

Evidens och kritiskt tänkande i vården. 174 s, tab, ill. Stockholm: Norstedts, 2009 Pris SEK 250

ISBN 978-91-1-302273-4

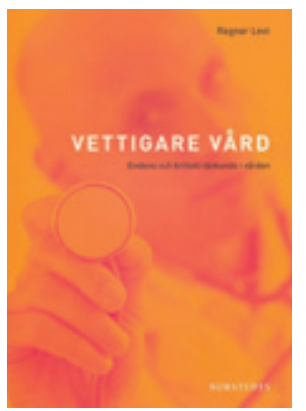

Det første er ikke å skade (primum est non nocere), er overskriften på introduksjonskapitlet. Ordene er fra Hippokrates 2400 år gamle. Fra epilogen framgår at når British Medical Journal i 2007 listet opp de

15 mest betydningsfulle milepælene siden 1840, var kunnskapsbasert medisin (EBM) på listen sammen med bl.a. oppdagelsen av DNA, antibiotika, vaksiner m.fl.

Kort fortalt handler boken om kunnskapsbasert medisins betydning for «vettigare vård». Fra sin studietid forteller forfatteren at «til allas besvikelse avslöjade aldrig förelesaren hur man blir en oskadlig av kapitlene faller i større eller mindre grad

doktor». Men etter den tid har Cochrane Collaboration og Statens beredning för medicinsk utvärdering (SBU), der forfatteren er informasjonssjef, bidratt til systematiske kunnskapsoversikter som har vist at helsetjenester både kan være ineffektive og i visse tilfeller skadelige. Sentrale begreper innenfor den kunnskapsbaserte medisinen omtales og vektlegges, slik som kunnskapsgrunnlag (evidens), randomisering, metaanalyse og systematiske litteraturoversikter.

Boken er skrevet for å bidra til mer kritisk og selvstendig tenking, og målgruppen er de som nå er under utdanning for å arbeide i helsetjenesten, men er også ment å inspirere de etablerte til å drøfte sine inngrodde rutiner og til å etterspørre kunnskapsgrunnlag. Det gjelder å få best mulig helse og livskvalitet for hver krone. Forfatteren vil også gjerne at legmenn, pasienter og pårørende skal gis et innblikk i hvilke krav som burde stilles til helsetjenester. For å fremme diskusjon og kritisk refleksjon avsluttes hvert kapittel med spørsmål.

Eksempel: Hvorfor er det utviklet bedre sikkerhetstenking for fly enn for helsetjenesten og hva kan gjøres for å bedre situasjonen? Finnes det noen medisinske informasjonskilder som du oppfatter som generelt mer troverdige enn andre? Hvorfor gir én enkelt studie sjelden nok støtte til at behandlingsrutinene bør endres?

Boken er velskrevet og lettlest og har morsomme tegninger. Den føyer seg inn $i$ en rekke av bøker og publikasjoner som vektlegger betydningen av kritisk tilnærming ad modum kunnskapsbasert medisin og anbefales som sådan.

Personlig ser jeg likevel frem til at det kommer verk som også vektlegger en annen form for kritisk tenking - nemlig om kunnskapsbasert medisin slik den fungerer i dag. Det foreligger et innebygd etisk kjerneproblem i den biomedisinske kunnskapsproduksjon som handler om medisinens vitenskapelighet, menneskesyn og kroppsforståelse. Synet på mennesket er gruppebasert og derfor fremmedgjørende, og kunnskapen som produseres, er abstrahert fra livet i kraft av metodene. Kroppen betraktes fragmentert, mekanistisk og materielt - og til det passer kunnskapsbasert medisin som hånd $\mathrm{i}$ hanske; hvert fragment tilbys sin kunnskapsbaserte terapi. Gyldig kunnskap - korrekt anvendt kan derfor også skade. Primum est non nocere.

\section{Irene Hetlevik}

Allmennmedisinsk forskningsenhet Institutt for samfunnsmedisin

Norges teknisk-naturvitenskapelige universitet

\section{Ny svensk lærebok i lungemedisin}

Sandström T, Eklund A, red.

Lungmedicin

478 s, tab, ill. Lund: Studentlitteratur, 2009

Pris SEK 651

ISBN 978-91-44-00847-9

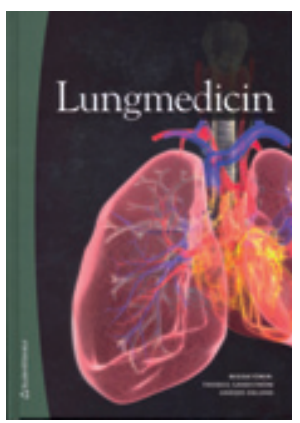

En skandinavisk lærebok tillater formidling av sykdommenes manifestasjoner og forløp i vår del av verden, og forfatterne vil vektlegge den lokale kultur og tradisjon i diagnostikk og behandling. Et slikt fokus har

ikke de store angelsaksiske lærebøkene som er siktet inn mot det globale marked. Denne svenske læreboken i lungemedisin er ifølge redaktørene rettet mot en lesergruppe av leger under spesialisering i lungesykdommer og spesialister i lungesykdommer, men den kan også være aktuell for leger i andre fagområder og interesserte sykepleiere.

I alt har 53 forfattere, hovedsaklig fra svenske universitetsklinikker, skrevet 35 sentrale kapitler innen lungemedisin. Her omtales de viktigste lunge- og luftveissymptomene hos pasientene som oppsøker helsevesenet, nemlig dyspné og hoste, og vanlige prosedyrer som lungeradiologi og allergidiagnostikk. Tradisjonelle store pasientgrupper er omtalt: de med astma i seks kapitler, kronisk obstruktiv lungesykdom (kols) i fem kapitler, parenkymatøse lungesykdommer i ti kapitler, lungeinfeksjoner inkludert tuberkulose $i$ tre kapitler. Men det er også kapitler om lungekreft, pleurasykdommer, cystisk fibrose, lungetransplantasjon, hypoventilasjon, obstruktiv søvnapné, yrkesrelaterte lungesykdommer, røykestopp samt rehabilitering. Omtalen av lungenes utvikling og pulmonal hypertensjon har fått større plass enn vanlig, men det skyldes vel den store kunnskapsutviklingen på disse fagområdene. Jeg savner et kapittel om lungembolisme og mer utførlig omtale av komorbiditet og systemmanifestasjoner ved kols. Det er store pasientgrupper som ofte tas hånd $\mathrm{om} \mathrm{av}$ spesialister i lungesykdommer. Boken har et fyldig register med ca. 1500 emner, men jeg savner et avsnitt som forklarer alle forkortelsene som brukes i boken. Referanser til andre bøker, tidsskriftsartikler og internettadresser er fåtallig, men jeg finner henvisninger til flere sentrale globale, engelske og svenske faglige retningslinjer innenfor lungemedisin. Flere av kapitlene har et sammendrag og en faktarute.

Læreboken er skrevet av erfarne klinikere med meget god innsikt i de aktuelle 